\title{
MESSAGES OF RELIGIOUS MODERATION EDUCATION IN SAMBAS ISLAMIC MANUSCRIPTS
}

\author{
Erwin Mahrus', Zaenuddin Hudi Prasojo², Busro 3 \\ ${ }^{1,2}$ State Institute for Islamic Studies (IAIN) Pontianak, Indonesia \\ Jl. Letjend Suprapto, Pontianak, West Kalimantan \\ Email: 'erwinmahrus@gmail.com, ²zaestain@yahoo.com \\ 3State Islamic University (UIN) Sunan Gunung Djati Bandung, Indonesia \\ Jl. Cimencrang Kec.Gedebage, Bandung \\ Email: busro@uinsgd.ac.id
}

\begin{abstract}
In the beginning of the $20^{\text {th }}$ century, West Kalimantan had a number of social issues, especially in the context of religious moderation. Both individuals and groups claim one another as being the most proper ones. Fom that condition, a negative impact occurred on social order in society. Observing to this situation, Muhammad Basiuni Imran, the Maharaja Imam to the Kingdom of Sambas, initiated a meeting of Islamic religious leaders and priests for the Western part of Borneo. This work is based on research conducted on manuscripts that recorded the speeches of West Kalimantan religious leaders and priests (alim ulama) in the meeting. Considering that this study is aimed at exploring the manuscripts, to approach the issue the authors employ philology that includes the inventory of manuscripts, identification of origins, compiling descriptions, making text summaries, and finally presenting messages of religious moderation education in the related texts. This study successfully concludes that those Islamic manuscripts of Sambas in West Kalimantan, including the manuscript by Maharaja Imam Sambas are on the end of extinction due to ages of century. The text is full of messages of religious moderation education as seen in the principle of flexibility and renewal (tajdîd), the principle of ease (taysîr), and the principle of tolerance (tasâmuh). Finally, the madrasa founded by Maharaja Imam Sambas is as among the oldest Islamic education institution that promotes religious moderation in West Kalimantan.
\end{abstract}

Keywords: religious moderation; education; Sambas; manuscript; Maharaja Imam.

Abstrak: Di awal abad ke-20, Kalimantan Barat mengalami berbagai isu sosial, khususnya yang berkaitan dengan masalah moderasi beragama. Setiap kelompok dan bahkan individu cenderung mengklaim kebenaran masing-masing dalam menyikapi kondisi soail yang ada dalam rangka parktik keberagamaan di Sambas. Kondisi tersebut telah berdampak negative pada keberlangsungan kehidupan sosial keagamaan dalam masyarakat. Menyikapi kondisi tersbut, Muhammad Basiuni Imron, Maharaja Imam Sambas, menginisiasi pertemuan yang mengundang para ulama dan tokoh agama Islam yang ada di wilayah Borneo bagian Barat kala itu. Artikel ini mengeksplorasi hasil pertemuan tersebut yang terekam dalam kumpulan manuskrip Islam yang ditulis oleh Maharaja Imam Sambas tersebut. Oleh karena itu penulis menggunakan pendekatan filologi yang meliputi inventarisir manuskrip, identifikasi asal manuskrip, penyajian deskripsi isi manuskrip, membuat kesimpulan isi teks, dan penyajian pesan-pesan tentag Pendidikan moderasi beragama yang dikandungi oleh teks. Tulisan ini menyajikan kesimpulan bahwa kumpulan manuskrip Islam di Sambas tersebut yang juga termasuk yang ditulis oleh Maharaja Iman Sambas ialah tergolong manuskrip langka dan berada pada kondisi yang meprihatinkan. Kompulan manuskrip tersebut mengandung banyak pesan tentang pentingnya Pendidikan moderasi beragama yang terkandung pada beberapa prinsip seperti tajdîd, tasyîr, dan tasâmuh. Akhirnya, madrasah sebagai institusi pendidikan Islam yang didirikan oleh Maharaja Imam Sambas merupakan salah dari beberapa institusi pendidikan Islam yang menjadi bukti gerakan mempromosikan moderasi beragama Kalimantan Barat.

Kata kunci: moderasi agama; pendidikan; Sambas; manuscript; Maharaja Imam.

\section{Introduction}

Religious moderation and education discourse has become an interesting issue. People in Indonesia have given serious attention to religious moderation, ${ }^{1}$ especially after the number of

${ }^{1}$ Adeng Muchtar Ghazali and Busro Busro, "Pendidikan Islam Dalam Dinamika Kehidupan Beragama Di Indonesia," 
violent events occurred due to the fact that they were in the name of religion, including at the local, national, regional and global levels. This research is considered important, not only because the content presented public attention, but also because as long as researcher's finding, after tracing some of the research results, no similar research based on the Islamic Sambas manuscripts in West Kalimantan found. The important issue for researchers to elaborate is the content of the West Kalimantan Religious Leader and priests Conference Speech text (It is abbreviated PKAU-KB) ${ }^{2}$ which contains authentic data on the principles of religious moderation in West Borneo, specifically in the Kingdom of Sambas in the early $20^{\text {th }}$ century. The success of revealing the contents of this manuscript contribute to the description of the presence of Islam in this region for the future.

The issue of religious moderation has become a trending topic in Indonesia since the office of the Ministry of Religious Affairs of Indonesia repromoted it in aerly 2015 when Lukman Hakim Saifuddin as the minister announced the urgency to redefine the issue for current situation of religious life. Some scholars have also published their important research findings related to religious moderation and its dynamics. They argue that the issue has been important and reluctant to the religious life in Indonesia. ${ }^{3}$ Some also believe that religious moderation should be the core of human interactions. Overall, the discource of religious moderation tends to be influenced by the issues of political and religious centiments. ${ }^{4}$

This work has come to explore the elements of education ans educational institutions in the efforts of fostering the emergence of religious moderation movements. In specific, this work attempts to supplement the roles of religious education in the history of the practices of Islam

Intizar, vol. 23, no. 1 (December 19, 2017), p. 93, https://doi. org/10.19109/intizar.v23i1.1615.

2 Muhammad Basiuni Imran, "Pidato Konferensi Alim Ulama Se-Kalimantan Barat,” (1948).

3 Abdurrohman Kasdi, "Wasathiyyah a as the Road to Moderatism in Indonesia," Al-Albab, vol. 8, no. 2 (2019), pp. 179-92, https://doi.org/10.24260/ALALBAB.V8I2.1356.

${ }^{4}$ M Maskur, "Eksistensi Dan Esensi Pendidikan Madrasah Di Indonesia," Jurnal Pendidikan Dan Pembelajaran Dasar, vol. 4, no. 1(2017). in Sambas of West Kalimantan in aerly time when Islam started to exist in the region. Religious institution was found profound having significant roles in the dynamic of religious life within the time of the Kingdom of Sambas. The fact that the manuscripts found in the region recorded the existance a madrasa (an Islamic education institution) initiated by a popular ulama in Sambas namely Maharaja Imam Sambas has been very interesting and significant to provoke the authors to explore further and introduce the findings to the wider audiences.

\section{Method}

This research is based on data found in the Islamic manuscript in Sambas of West Kalimantan. Philology is employed to approach the issue of religious moderation and education in the era of the life of Maharaja Imam Sambas. Philological research steps are conducted consisting of manuscript inventory, identification of the origin of manuscripts, manuscript descriptions, summaries of text contents and religious moderation messages in PKAU-KB manuscripts. This text are read and analyzed carefully and then interpreted qualitatively refering to the study problems prepared previously.

\section{Frame of Theory}

The word moderation comes from the Latin moderatio, which means medium (not excess and not lacking). ${ }^{5}$ According to the Indonesian Main Dictionary(KBBI), moderation is proposed in two intrepetation: (1) reducing violence; (2) avoidance of extremes. ${ }^{6}$ In English, the word moderation is often commonly used in the meaning of average, core, standard, or non-aligned. Whereas in Arabic, moderation is known as the word wasath or wasathiyah which has the equivalent meaning with the word tawassuth (middle).? Moderation (al-wasathiyah) is a balance between two ways or opposing two ways or two directions, which one of the two

\footnotetext{
5 Kementerian Agama, Moderasi Beragama (Jakarta: Badan Litbang dan Diklat Kementerian Agama RI, 2019), p. 15.

${ }^{6}$ Tim Penyusun, Kamus Besar Bahasa Indonesia (Jakarta: Balai Pustaka, 1990), p. 589.

7 Kementerian Agama, Moderasi Beragama..., p. 16.
} 
parties cannot take rights more to other and overlap the other. ${ }^{8}$ Qardawi divides the various types of moderation into several fields: First, ideology. In ideological view, Islam is not a religion that cults humans, but on the contrary neither considers humans as slaves. Second, ritual worship. Islam is a religion that emphasizes worship but still encourages the people to be productive. Not only emphasizing the aspect of rubûbiyah, but also insâniyah. Third, morality (morals). In this context, humans are seen as beings who have animalistic instincts but also angelic spirituality. ${ }^{9}$

Identification of a particular religious behavior can be classified as moderate or vice versa as extreme requires benchmarks, indicators, and limits. These benchmarks can be made based on reliable sources, such as religious texts, state constitutions, local wisdom, consensus or collective agreement. ${ }^{10}$

Based on a literature review, religious moderation in Islam has a number of principles. First, the principle of flexibility and renewal (tajdîd). One indicator of moderate Islam is that it is easy to accept renewal and can adjust to the circumstances of the masâlih fî kulli makân wa zamân. ${ }^{11}$ This is the character of the religion of Islam peacefull/ rahmatan lil 'âlamîn. Second, ease (taysîr). Islam was revealed to provide convenience to the worshipers. According to Amin's study, there are many Quranic verses that present about (1) the principle of ease in religion: "Allah wants for you ease and does not want difficulties" (Surah Al-Baqarah [2]: 185); (2) The principle of eliminating narrowness: "Allah does not want you to be narrow but He wants to purify you" (Surah Al-Mâidah [5]: 6); (3) The principle of relief (takhfîf): "Allah wants to lighten for you and humans were created in a weak state" (Q.S. Al-Nisa' [4]: 28). ${ }^{12}$

\footnotetext{
${ }^{8}$ Yusuf Al-Qardhawi, Al-Khashaish Al-'Ammah Li Al-Islam, trans. Rofi'i Munawar and Tajuddin, (Jakarta: Risalah Gusti, 1995), 141.

${ }^{9}$ Yusuf Al-Qardhawi, Al-Khashaish..., pp.150-160

${ }^{10}$ Kementerian Agama, Moderasi Beragama..., p. 18.

"M. Quraish Shihab, Membumikan Alquran (Bandung: Mizan, 1996)

${ }^{12}$ Rauf Amin, "Prinsip Dan Fenomena Moderasi Islam Dalam Tadisi Hukum Islam,” Al-Qalam, vol. 20, no. 3 (2014), pp. 23-32.
}

Third, tolerance (tasâmuh). In Arabic the most common used word to represent the word tolerant is tasâmuh, derived from the word samhan meaning easy, convenience or ease. Tolerance in religion means one's attitude to allow differences, delay judgment and understand why other people believe and behave differently from themselves and let them express their religious experience without interference and threats. ${ }^{13}$

\section{Result and Discussion General description of PKAU-KB Manuscript}

As described previously, this section is described starting from the inventory of the manuscript, the origin of the manuscript, the description of the manuscript, a summary of the contents of the text and religious moderation messages in the PKAU-KB manuscript.

Seen from the aspect of inventory, the PKAU$K B$ manuscript for the time being is only found in a collection of manuscripts. Apart from not having the number and code of the manuscript variant or text version of this manuscript, it is not found in the catalog of manuscripts that have been published, either manual or digital.

It is seen from the aspect of inventory, the PKAU-KB manuscript for the temporary until now is only found in a collection of manuscripts. It does not have the number and code of the manuscript or text version of this manuscript, it is not found in the catalog of manuscripts that have been published, neither manually or digitally.

The origins of the PKAU-KB text come from a village on the banks of the Subah River, Sambas. The village is known by the name Kampung Dagang Timur which is located in Sambas District, Sambas Regency, West Kalimantan Province. This manuscript is stored in a heritage home of Maharaja Imam Sambas, ${ }^{14}$ H. Muhammad Imran.

13 Dody S. Truna, Pendidikan Agama Islam Berwawasan Multikulturalisme (Jakarta: Kementerian Agama RI, 2010), p. 354.

${ }^{14}$ Maharaja Imam is the highest title for religious officials in the Kingdom of Sambas, Sunandar Sunandar, "Resonansi Maharaja Imam Muhammad Basiuni Imran (1885-1976) Di Sambas," Medina-Te : Jurnal Studi Islam, vol. 15, no. 1 (August 2, 2019), pp. 75-91, https://doi.org/10.19109/medinate.v1511.3542. See also Erwin Mahrus, "Prototype of the Arab School in the Kingdom of Sambas of West Borneo in the Early 2oth Century," in International Conference on Islamic Education (ICIE 2018) (Atlantis Press, 2018). 
This house, by the Sambas Regency Government around 2002, was converted as a museum that was named the Nagri Sambas Islamic Tamadun Museum. Researchers found this text when doing research on the History of the Sultanate of the archipelago with the team. This research was carried out in collaboration between the Research and Development Agency of the Literature and the Religious Khazanah of the Indonesian Religion Ministry and STAIN (State Islamic Campus) Pontianak in 2010. Researchers were then allowed to digitize this manuscript by museum officials.

Because it does not have its own number and code, PKAU-KB manuscript seems to have never been examined or published by any party. This manuscript has a colophon that contains information about the name of the copyist. The text on the colophon is written: "By the Chairperson of the religious leader and priest Conference Haji Muhammad Basiuni Imran Maharaja Imam Adviseur of Religion and the Sambas Commission Bestuur". The physical condition of this manuscript, from mild to severe damage. At the bottom of the script is fragile and eaten by termites. At the top right edge rather inward, has been hollowed out due to exposure to iron rust which may be used as a paper clip. Along the top and bottom edges are fragile and yellowish due to the high acidity in the paper.

The PKAU-KB manuscript consists of 7 pages with 7 pages, in other words this script was only written with one front page per sheet. This type of base material was bluish colored lined paper. Therefore, this script did not have a watermark and countermark. The writing in this manuscript used entirely black ink and readability quite clearly. The number of lines of text per page is an average of 35 lines according to the number of lines available which also amounts to 35 lines. Thus, almost all parts of the paper are used up, except the space on the right margin is $2.5 \mathrm{~cm}$ from the edge of the paper.

The size of this manuscript is $27.5 \times 20.5 \mathrm{~cm}$, while the size of the text in the manuscript is $26.5 \times 17.5 \mathrm{~cm}$. This work has a page numbering, but it did not have a word of apology, such as other Sambas texts. This script used Arabic letters with Malay language or commonly called Jawi script. The type of script used in this manuscript is similar to riq'ah and naskhî, although it did not fully follow the standards of writing of these two types of calligraphy.

While the summary of the contents of the PKAU-KB text is as follows: Page 1 contained an appreciation of the presence of the members or legislators and the objectives to be achieved from the conference. Page 2-5 discussed 10 characteristics of Islamic teachings, including principles in religious moderation. Page 6 contained a study of the condition of Muslims in West Kalimantan who are in a weak state. Page 7 included concluding remarks and gratitude.

It is seen from the background of writing a manuscript, as it is understood that a manuscript is not present in a vacuum, but appears to be covered by the dynamics that surround it. This text was intentionally written by Basiuni who is also the chairman of the religious leader and priest or Alim Ulama Conference in West Kalimantan. Unfortunately, this manuscript does not include the date and year the manuscript was written. However, in the text of al-Murasâlat al-'Ilmiyah information was obtained that the conference was held in November 1948. ${ }^{15}$ Likewise the names of the participants or invitations at the conference. But in the correspondence there are mentioned several names such as Muhammad Akib and Kurdi Ja'far from Mempawah. ${ }^{16}$ Then at the beginning of the PKAU-KB text, it was emphasized that the conference participants came far from sambas and origins from various regions of West Kalimantan. ${ }^{17}$

The reason of the held of the conference was because of the influence of the development of Muslims in West Kalimantan in the early $20^{\text {th }}$ century. Some information about the condition of the people in the West Kalimantan is also stated in the Basiuni correspondence to some of his colleagues in Egypt. One of the letters for example he addressed to Sheikh Yusuf Yasin, secretary of Ibn Saud, King of Saudi . Basiuni

\footnotetext{
${ }^{15}$ Muhammad Basiuni Imran, “Al-Murāsalāt Al-'Ilmiyah,” n.d.

${ }^{16}$ Muhammad Basiuni Imran, "Surat Kepada Kurdi Ja'far, 8 Muharam 1376 H, Manuscript,” 1376.

${ }^{17}$ Muhammad Basiuni Imran, "Pidato Konferensi..., (1948)
} 
illustrates that the Jawi community is still oldfashioned and not understand comprehensive about religion, and the number of madrasas (Islamic school) is still very small in number. Similarly, the number of ulama (Islamic preacher and religious leader and priest) is lack in number compared to the population of this island. ${ }^{18}$

This text also explicitly mentions the organizer of this conference, the Association of Islah Baitul Mal (IBM). This association was founded on December 25, 1947 to coincide with 11 Safar 1367. The pioneering figure was $\mathrm{KH}$. Abdurrani Mahmud, H. Masyhur Riva'ie, H.A. Moeis Idris, M.K. Indera mahyudin and H. Bainuddin Ahmad. ${ }^{19}$ If it is observed deeply, the goals in the rules of Association and Bylaws of the IBM Association, article 4 are mentioned: (1) Speed up and reinforce a sense of religious brotherhood with no regard for high or low degrees and nation. (2) Expanding the teachings of Islam with the broadest possible meaning of the word. ${ }^{20}$

As mentioned earlier, the author of this manuscript is $\mathrm{H}$. Muhammad Basiuni Imran (then referred to as Basiuni). He was born in Sambas, West Kalimantan on 25 Zulhijjah 1302 H (October 16, 1885 AD). He received religious education for the first time from his parents, then entered the elementary School (sekolah rakyat). ${ }^{21}$ At a very young age, aged 16 years, he performed the pilgrimage at the same time also living and studying there for 5 years in the 1901-1906.22 In 1907 AD, he returned to Sambas on the orders of his father. From then on, he began subscribing to the Al-Manar Journal and reading literature from Egypt. ${ }^{23}$ Two years later, 1909,

${ }^{18}$ Muhammad Basiuni Imran, "Surat Kepada Syekh Yusuf Yasin, 7 Rabiul Awal 1345 H, Manuscript," 1345.

19 Mulyadi, "Kiprah Yayasan Ishlah Baitul Mal (IBM) Pontianak Dalam Pendidikan Agama Islam Di Pontianak" (Pontianak, 2001).

20 Perkumpulan Ishlah Baitul Mal, "Anggaran Dasar Perkumpulan Ishlah Baitul Mal, Disalin Ulang Oleh Mulyadi" (Pontianak, n.d.).

${ }^{21}$ G.F. Pijper, Beberapa Aspek Tentang Islam Di Indonesia, trans. Tudjimah (Jakarta: UI Press, 1987), 142.

${ }^{22}$ Muhammad Basiuni Imran, "Daftar Sedjarah Perdjalanan Hidup Dari Hadji Mohammad Basioeni Imran, Maharaja Imam Sambas,manuscript," 1950.

${ }^{23}$ A. Muis Ismail, "Riwayat Hidup Maharaja Imam Sambas, H. Muhammad Basiuni Imran” (Pontianak, 1993), 143.
Basiuni went to Egypt to continue his education at al-Azhar University. Not for long time, at this oldest university in the world, he continued his education al-Dâr al-Da'wah wa al-Ershad in Manyal (Old Cairo) founded by Sheikh Muhammad Rasyid Ridha. Four years of education in Egypt, Basiuni had to return to Sambas, because his father was seriously ill. Soon, his father passed away. After his father's death, he was trusted by the Sultan as Maharaja Imam in Sambas Kingdom, in 1913.

Even though he returned from Egypt, it did not make Basiuni less enthusiasm to explore Islamic sciences, especially Jurisprudence and interpretation. To add knowledge and insight into the Islamic world including the development of education, Basiuni subscribed to magazines and newspapers such as: Fajar Asia, Al-Muslimûn Al-Fara ', Al-Ma'ârif al-Qurrâ, Al-Fath, and Umm al-Qurân. ${ }^{24}$ The discourse, which was developed in a number of journals and magazines subscribed to, became the foundation of Basiuni's future thinking and acting.

Basiuni also left a number of writings in the form of books published in the Middle East, Singapore, Malaysia and the country. His published works reached 10 (ten) pieces with various Islamic disciplines ranging from monotheism, fiqh, interpretation (ulûm al-qurân), and history. He also left a number of manuscripts in the form of manuscripts, diaries, and correspondence.

\section{Moderation Messages PKAU-KB Manuscript}

PKAU-KB manuscript contains several texts that contain messages of religious moderation that refer to the following principles:

\section{The flexibility principle and tajdîd (renewal)}

One indicator of moderation is always to be open to updates. Islam is a religion that is always flexible in every situation and change of the times. The main spirit is to provide benefit for humans. Basiuni said:

That Allah has made Islam a straight path to perfect all things of human beings on their matters in spirit and body so that it will be a wasi - medium- for sa'â dah - the good

\footnotetext{
${ }^{24}$ Muhammad Basiuni Imran, “Al-Murasalat Al-'Ilmiyah.”
} 
of the world and the hereafter ... As the matters of law and siasah - politics -, then whatever is different from other causes of time and place, then Islam has revealed its origin and basics ... all texts than that which agree with the benefit of humans in each place and time." 25

In another part of this text, Basiuni also advised:

That Allah has surrendered to the Muslims of all matters of their world which is for themselves or a unique alliance and on the condition that they do not damage the world of their religion and do not damage their sharia instructions. Then Allah has made the origin of all things halal or must be forbidden to be prohibited from something but by the argument because of legal origin. ${ }^{26}$

A flexible attitude also appears from polite and non-violent behavior and judging that something is only black and white. When asked by the Muhammadiyah executive in Yogyakarta, in an forum on discussion of religious practices in Sambas, in connection with his position as imperial priest and imperial mufti, Basiuni firmly replied: “I don't want to be hard because I am afraid of slander. Prophet Muhammad, PBUH began to practice (religion) slowly". ${ }^{27}$

Violent and abusive behavior, instead of getting respect from others, on the contrary people will avoid and / or mock back. In this case Basiuni advised: "If you ask people to be respected, then you should be knowledgeable and behave well. Even about words or deeds". ${ }^{28}$

\section{Principle of taysîr (Simplicity)}

As a moderate religion, Islam is not a strict religion. quoted verses and hadith about the characteristics of this one Islamic moderation:29

It is not desired that Allah will make above you religion rather than shortsightedness." ${ }^{30}$ "And we make it easy for you to exceed

${ }^{25}$ Muhammad Basiuni Imran, "Pidato Konferensi..., pp. 3-4.

${ }^{26}$ Muhammad Basiuni Imran, "Pidato Konferensi ..., p. 2.

${ }^{27}$ Muhammad Basiuni Imran, "Pelayaran Ke Tanah Jawa, Manuscript," 1932, 19.

${ }^{28}$ Muhammad Basiuni Imran, "Pidato Konferensi..., p. 14.

${ }^{29}$ Muhammad Basiuni Imran, "Pidato Konferensi..., p. 2.

${ }^{30}$ Q.S. Al-Haji [22]: 78 the Sharia with ease". ${ }^{31}$ "That this is a religion that is easy and does not trigger the religion by someone but he will defeat him". 32 "“"Make it easy for you and do not trouble (memayakan) and like or tame by you and do not let you".33

In his other work, Basiuni said:

"And our only intention here is to state that the prosperity of sjariat and wisdom of tasjri and the state of ijtihad is a mercy for the worshipers ... the dignity and elevation of prominence and the refusal of all heroism and the benefit of the masses and the' oerf or 'custom and so on rather than the mercy of the devil ... the dignity and uplift of prominence and the refusal of all virtues and the benefit of the masses and the affection of the' oerf or 'custom etc. that is not from general qâ'idah". 34

\section{Principle of tasâmuh (tolerance)}

Islam is a religion that upholds tolerance. In Basiuni's view, tolerance is aimed at at least two groups: First, tolerant of people of the same religion. To this first group Basiuni always stressed the importance of unity. His statement has never escaped the argument of the Quran, he said:35

That Islam is the religion of tawhîd dan ijtimâ' (association and unity) and that he strongly upholds guilt and split ... "Hold on to the leash of Allah, that is the Quran and do not devided you". 36 "And do not be like those who have been divided and blame later than items which have come to them by information." 37

Other Basiuni works that also contain about religious moderation. In the al-lbânatoe script for example he highlights seriously the attitude of the Muslims in West Kalimantan:

"brothers and sisters, aren't we Muslims who should be better off avoiding mockery and entitled with evil titles of nations and religions

${ }^{31}$ Q.S. Al-A'la [87]: 8

${ }^{32}$ HR. Ibn Hibban no. 351

33 HR. Bukhari no. 69; dan Muslim no. 1733

34 Muhammad Basiuni Imran, "Al-Ibānatoe, Manuscript," 1933, p. 73.

${ }^{35}$ Muhammad Basiuni Imran, "Pidato Konferensi..., p. 4.

${ }^{36}$ Q.S. Ali Imran [3]: 103

${ }^{37}$ Q.S. Ali Imran [3]: 105 
fellow for reasons of misunderstanding or thinking on one problem." ${ }^{38}$

In an al-lbânatoe script, Basiuni also emphasized the same thing: "Now our Moeslimin in Indonesia and in the Land of Melajoe are in dispute and argue in religious matters from the matter of matters of practice and i'tiqad..." 39 In its correspondence with the editor of the alManar journal, Basiuni also revealed how religious moderation began to be disturbed, due to not being able to refrain from addressing each other's differences:

"... heats up among us Malays are now in a lot of quarrels and fights among blind fanatics and people who like reform and make improvements. And I see that the impact is not good, even it has a huge disadvantage compared to its benefits..." 40 In the Book of al-Janâiz, Basiuni revealed: "... Disputes arose itself which is strictly forbidden by God, which is greater than the mudharat of talkin. ${ }^{41}$ By quoting Ibn Taymiyyah's opinion, Basiuni said: “Ma'loem that taming all hearts is greater in religion than half sunnah (moestahab-moestahab) then if leaving someone by him for taming all his hearts is greater than that of half sunnah (moestahab-moestahab) then if someone leaves him by taming him, he will tame all hearts. That is good ... " 42

One disadvantage for Muslims especially in West Kalimantan, is the friction in the community like this will only aggravate the situation. On the one hand, internally the condition of Muslims is indeed underdeveloped from all aspects, as will be explained in the next section. Whereas on the other hand, externally their conditions at that time were still under the influence of colonialism.

In addition to common people who argue one another, Basiuni also addressed his appeal to religious leaders not to easily refer to other people with different views as inappropriate. In

\footnotetext{
${ }^{38}$ Muhammad Basiuni Imran, “Al-Ibanatoe..., p. 73

39 Muhammad Basiuni Imran, “Al-Ibanatoe..., p. 73

40 Muhammad Basiuni Imran, "Al-Imda' Min Sambas," Jurnal Al-Manar, vol. 31, no. 5 (1930), pp. 347-52.

41 Muhammad Basiuni Imran, Al-Janaiz (Tasikmalaya: Percetakan Galunggung, 1943), p. 31.

${ }^{42}$ Muhammad Basiuni Imran, “Al-Ibanatoe..., p. 115.
}

chapter 23 of the book al-Ibânatoe, he stressed: "stay away and avoid by moefti will say heresy and disbelief".. ${ }^{43}$ Cursing and berating is not the character of a person who is cultured. In the book of Cahaya Suluh he again warns about the qualities that must be shunned by a Muslim: “... don't cursing and insulting other in public because that is not the qualities of noble and perfect people. " 44

Secondly, tolerance towards non-Muslims, Basiuni also maintains active harmony. In one of his appeals, he said that West Kalimantan Muslims should pay attention to the followers of other religions who have long worked seriously in developing religion in this country from the coast to the interior with their wealth and energy. Muslims must rise and not stay silent. ${ }^{45}$

"... That we as Muslims must remain obliged above us to pay attention to people of other religions who are - but have long - been active and working to truly develop their religion in our countries in all places and corners and in remote areas with energy and property ... Then than that is it also necessary for us to remain silent and sleep well not to fulfill our obligations towards our religion Islam?"

If taking attention to the message above, we will get the statement that the tolerance that want to built by Basiuni is in the context of fastabiq al-khairât. This is supported for example from his appeal when inviting Muslims in Sambas to donate some of the wealth to public benefit such as madrasa development. He said that the community's concern in making donations was not yet equal to the assets they owned. Basiuni then compared it to the spirit of sacrifice of the Jews. For him, it is this spirit that makes them achieve progress, while Muslims are still far behind. ${ }^{46}$

In one of the diary manuscripts, Basiuni asserted that the al-Sultaniyah madrasa which he had founded closed the oldest madrasa in West

\footnotetext{
${ }^{43}$ Muhammad Basiuni Imran, "Al-Ibanatoe..., p. 115.

44 Muhammad Basiuni Imran, Cahaya Suluh (Singapura: Matbaah al-Ahmadiyah, 1920), pp. 18-19.

45 Muhammad Basiuni Imran, "Pidato Konferensi..., p. 6.

${ }^{46}$ Muhammad Basiuni Imran, "Membelanjakan Uang Di Jalan Allah Ialah Jalan Kemajuan, Manuscript,” 1938.
} 
Kalimantan, because of respect for the Catholic religious holiday in Sambas. ${ }^{47} \mathrm{His}$ position as a religious figure in Sambas is also described as someone who socializes with anyone even with a catolict priest, who visits him at every Eid alFitr. ${ }^{48}$ In the context of social relations among them to non-Muslims, he advised: "Be a polite and graceful person. Never hate or antagonize other people." 49

\section{Religious Moderation Factors}

In the final part of the PKAU-KB text, Basiuni saw how many weaknesses were afflicting Muslims at that time. He then traced a number of problems faced by these Muslims:

As for the state of Islam and its people in all our countries from West Kalimantan, I believe respective people, noble brothers and sisters who will acknowledge and justify my words that Islam and its people are very dha'if and backward either about science or even aqâ'id islamiyah (trust), the laws of worship, muamalah, behavior, tarbiyah islamiyah - Islamic education - and so on. ${ }^{50}$

According to the $3^{\text {rd }}$ Maharaja Imam Sambas, the weaknesses of Muslims in West Kalimantan can be identified from a number of weaknesses in the following aspects: (1) science; (2) usûl al-dîn; (3) jurisprudence; (4) morals (behavior). (5) Tarbiyah Islamiyah (Islamic Education). If examined further, these weaknesses are also, directly or indirectly, a trigger for the lack of religious moderation.

First, Basiuni firmly argues that Muslims must master various disciplines of sciences. "Calling [to goodness] is our duty, but of course the caller needs to have perfect knowledge and other conditions needed for the success of his business. apart from that, it is also necessary to know the condition of the person being diseur; Jurisprudence, history, jughrafi, psychology, 1926.

${ }^{47}$ Muhammad Basiuni Imran, "Buku Harian, Manuscript,"

48 Gusti Muhammad Ardhi, "Pemikiran Politik Dan Kenegaraan H. Muhammad Basiuni Imran,” n.d.

${ }^{49}$ Muhammad Basiuni Imran,"Pelayaran Ke Tanah Jawa, Manuscript."

${ }^{50}$ Muhammad Basiuni Imran, "Pidato Konferensi..., p. 6. morals, sociology, politics and others. ${ }^{51}$

In fact he detailed a number of knowledge that must be possessed by Muslims, in addition to religious knowledge, of course: "Apart from that, it is also necessary to say:

"If we still want to spend our time or ages on reading the books of our people who are blind to it and not as faithful to the books of the Mujtahidin Imams ... If there is such a thing we need to be bad people, we are as devilish in our faith and as dumb as in religious matters let alone other matters." ${ }_{52}$

Second, knowledge of the basics of belief (usûl al-dîn; aqâ'id, or tawhîd). Basiuni said: “... There is no need for you to say someone who is Muslim; infidel, even though he was ignorant (not knowing) about usûl al-dîn. Only you will tell him to sue him or teach him if you know." 53 That is, it is inappropriate for a Muslim to call another Muslim an infidel simply because he does not know the main points of the religious teachings.

Third, insight into the science of Jurisprudence and its development Jurisprudence can be said to be one of the most popular branches of science in Islamic studies compared to other branches of science, because this science governs a Muslim from his birth until he dies. Therefore, issues relating to religious moderation are contributed by most of this science. Basiuni is a figure who specifically wrote a book about addressing differences in fiqh affairs. The book is titled alIbânat wa al-Insaf fî al-Masâil al-Diniyah wa izalat al-Tafarruq fîha wa al-Ikhtilâf.

"Learn the knowledge well and logical. Do not continue to believe the words of people who like to criticize not with reason." 54

Fourth, morals (behavior). Moral in Basioni's view is related to the mentality of a person or community. Basiuni said that the progress of Muslims in their heyday, expanded to the East and West and even to the whole world, partly because of their courage to sacrifice property and

${ }^{51}$ Muhammad Basiuni Imran, "Tugas Mulia Dan Tanggung Jawab Umat Islam Kepada Tuhan, Manuscript," 1967, p. 2.

${ }^{52}$ Muhammad Basiuni Imran, "Al-Ibānatoe..., p. 109.

53 Muhammad Basiuni Imran, Bidāyat Al-Tawhīd Fĩ Ilm AlTawhīd (Singapura: al-Mațba'ah al-Ahmadiyah, 1934), pp. 1-2.

${ }^{54}$ Muhammad Basiuni Imran, "Pelayaran..., p. 21. 
souls in defense of religion and homeland.. ${ }^{55} \mathrm{He}$ further said that the condition of the early $20^{\text {th }}$ century Muslims was in contrast to the situation of the early Muslims. Their condition is now stubborn, cowardly, cowardly, shy is not the place. As a result, Muslims are left behind in all aspects and are in disdain". ${ }^{56}$

Fifth, Islamic education. The most effective media to immerse culture is through education. Religious moderation is also related to the availability of educational institutions that teach about the importance of this attitude in religion. In its correspondence, Basiuni only mentioned the three Malay kingdoms in West Kalimantan which had formal Islamic educational institutions namely Sambas, Mempawah and Pontianak, ${ }^{57}$ without specifying the names of the educational institutions in the three kingdoms. Bruinessen, ${ }^{58}$ indicated an Islamic educational institution called al-Sulthaniyah. Mahmud, 59 also mentioned the Islamic educational institution in his work on scholars and surau in West Kalimantan. Whereas Yunus $^{60}$ mentioned three Islamic educational institutions during the colonial era, namely the al-Sulthaniyah madrasa, the Falah wa al-Najah madrasa, and the Raudhatul Islamiyah madrasa. According to Ahok et al, ${ }^{61}$ there are three Islamic educational institutions in this era, respectively the al-Sultaniyah madrasa, Islamic madrasa and al-Hasan madrasa. ${ }^{62}$ Meanwhile, according to Mahrus, there were at least four madrasahs that stood in the early 2oth century, respectively: al-Sultaniyah, Sambas (1916), al-Najah wa alFalah, Mempawah (1922), Madrasah Islamiyah,

55 Muhammad Basiuni Imran, “Membelanjakan Uang Di Jalan Allah Ialah Jalan Kemajuan, Manuscript," p. 3.

56 Muhammad Basiuni Imran, "Membelanjakan Uang..., p. 3 .

57 Muhammad Basiuni Imran, "Surat Kepada Syekh Yusuf Yasin, 7 Rabiul Awal 1345 H, Manuscript.”

58 M.M van Bruinessen, "Basyuni Imran,(Muhammad Basyuni B. Muhammad Imran, Sambas, West Borneo, 18851953)" (Utrecht University Repository, 1992).

${ }^{59}$ Abdurrani Mahmud, "Peranan Ulama Dan Fungsi Surau Di Kalimantan Barat” (Pontianak, n.d.).

${ }^{60}$ Mahmud Yunus, Sejarah Pendidikan Islam Di Indoenesia (Jakarta: Mahmud Yunus wadzuriyyah, 2008), p. 147.

61 Pasifikus Ahok, Sejarah Pendidikan Daerah Kalimantan Barat (Pontianak: Dapartemen Pendidikan dan Kebudayaan Kalimantan Barat, 1983), pp. 36-40.

${ }^{62}$ Madrasah al-Hasan is the forerunner of the madrasah Raudhatul Islamiyah.
Pontianak (1926), and Madrasah Waqf Board Raudhatul Islamiyah, Pontianak (1936). ${ }^{63}$ The madrasahs generally provide religious and moral educations, but there are also madrasahs that teach general science. ${ }^{64}$ Observing the condition of madrasahs in West Kalimantan in the Colonial era, it was clearly alarming. The availability of this institution is far from adequate, if compared to the population of the western part of Kalimantan Island. Islamic education institutions are only only available in the coastal areas as in the three regions mentioned above and have not touched at all inland regions whose numbers are much higher.

\section{Conclusion}

The manuscripts in West Kalimantan up to now have not been much studied and published, while the condition is increasingly endangered. These texts contain many important materials, including the issue of religious moderation education. Basiuni as the writer of this manuscript is a figure who is actively involved in intellectual debates in West Kalimantan on related issues. The messages of religious moderation education in the manuscripts can be traced through a number of principles such as flexibility and openness to reform, the principle of taysîr (easiness) in the implementation of Islamic teachings, and the principle of tolerance. The low factor of religious moderation is exacerbated by the weaknesses experienced by Muslims in the early to mid- $20^{\text {th }}$ century, among others, the lack of knowledge, the limited insight on the science of jurisprudence and its development, and the limited quantity and quality of Islamic educational institutions.

\section{References}

Ahok, Pasifikus, Sejarah Pendidikan Daerah Kalimantan Barat. Pontianak: Dapartemen Pendidikan dan Kebudayaan Kalimantan Barat, 1983.

${ }^{63}$ Erwin Mahrus, Sejarah Pendidikan Islam (Pontianak: IAIN Pontianak Press, 2013), p. 159. See also Erwin Mahrus, Menyongsong Seabad Perguruan Islamiyah Kampung Bangka Pontianak (Pontianak: IAIN Pontianak Press, 2015), pp. 15-17.

64 Soedarto, Sejarah Kebangkitan Nasional Daerah Kalimantan Barat (Pontianak: Departemen Pendidikan dan Kebudayaan RI, 1978), p. 49. 
Al-Qardhawi, Yusuf, Al-Khashaish Al-‘Ammah Li Al-Islam. Translated by Rofi'i Munawar and Tajuddin. Jakarta: Risalah Gusti, 1995.

Amin, Rauf, "Prinsip Dan Fenomena Moderasi Islam Dalam Tadisi Hukum Islam," Al-Qalam, vol. 20, no. 3, 2014.

Ardhi, Gusti Muhammad. "Pemikiran Politik Dan Kenegaraan H. Muhammad Basiuni Imran," n.d.

Bruinessen, M M van. "Basyunilmran, (Muhammad Basyuni B. Muhammadlmran, Sambas, West Borneo, 1885-1953)." Utrecht University Repository, 1992.

Ghazali, Adeng Muchtar, and Busro Busro. "Pendidikan Islam Dalam Dinamika Kehidupan Beragama Di Indonesia." Intizar, vol. 23, no. 1, December 19, 2017. https://doi.org/10.19109/ intizar.v23i1.1615.

Imran, Muhammad Basiuni, "Al-Ibānatoe, Manuscript," 1933.

__, "Al-Imda' Min Sambas." Jurnal Al-Manar, vol. 31, no. 5, 1930.

___, Al-Janaiz, Tasikmalaya: Percetakan Galunggung, 1943.

—_, "Al-Murāsalāt Al-‘llmiyah," n.d.

—_ Bidāyat Al-Tawhìd Fì Ilm Al-Tawhìd. Singapura: al-Mathba'ah al-Ahmadiyah, 1934.

__, "Buku Harian, Manuscript," 1926.

-, Cahaya Suluh. Singapura: Matbaah alAhmadiyah, 1920.

_ , "Daftar Sedjarah Perdjalanan Hidup Dari Hadji Mohammad Basioeni Imran, Maharaja Imam Sambas,manuscript," 1950.

___, "Membelanjakan Uang Di Jalan Allah Ialah Jalan Kemajuan, Manuscript," 1938.

__, "Pelayaran Ke Tanah Jawa, Manuscript," 1932.

____, "Pidato Konferensi Alim Ulama SeKalimantan Barat," 1948.

—_, "Surat Kepada Kurdi Ja'far, 8 Muharam 1376 H, Manuscript," 1376.

__, "Surat Kepada Syekh Yusuf Yasin, 7 Rabiul Awal 1345 H, Manuscript," 1345.

__, "Tugas Mulia Dan Tanggung Jawab Umat Islam Kepada Tuhan, Manuscript,” 1967.

Ismail, A. Muis, "Riwayat Hidup Maharaja Imam Sambas, H. Muhammad Basiuni Imran." Pontianak, 1993.
Kasdi, Abdurrohman, "Wasathiyyah Islam as the Road to Moderatism in Indonesia." Al-Albab, vol. 8, no. 2, 2019. https://doi.org/10.24260/ ALALBAB.V812.1356.

Kementerian Agama, Moderasi Beragama. Jakarta: Badan Litbang dan Diklat Kementerian Agama RI, 2019.

Mahmud, Abdurrani, "Peranan Ulama Dan Fungsi Surau Di Kalimantan Barat.” Pontianak, n.d. Mahrus, Erwin, Menyongsong Seabad Perguruan Islamiyah Kampung Bangka Pontianak. Pontianak: IAIN Pontianak Press, 2015.

_- "Prototype of the Arab School in the Kingdom of Sambas of West Borneo in the Early 2oth Century." In International Conference on Islamic Education (ICIE 2018). Atlantis Press, 2018.

_ Sejarah Pendidikan Islam. Pontianak: IAIN Pontianak Press, 2013.

Maskur, M, "Eksistensi Dan Esensi Pendidikan Madrasah Di Indonesia." Jurnal Pendidikan Dan Pembelajaran Dasar, vol. 4, no. 1, 2017.

Mulyadi, “Kiprah Yayasan Ishlah Baitul Mal (IBM) Pontianak Dalam Pendidikan Agama Islam Di Pontianak." Pontianak, 2001.

Perkumpulan Ishlah Baitul Mal, "Anggaran Dasar Perkumpulan Ishlah Baitul Mal, Disalin Ulang Oleh Mulyadi." Pontianak, n.d.

Pijper, G.F, Beberapa Aspek Tentang Islam Di Indonesia. Translated by Tudjimah. Jakarta: UI Press, 1987.

Shihab, M. Quraish, Membumikan Alquran. Bandung: Mizan, 1996.

Soedarto, Sejarah Kebangkitan Nasional Daerah Kalimantan Barat. Pontianak: Departemen Pendidikan dan Kebudayaan RI, 1978.

Sunandar, Sunandar, "Resonansi Maharaja Imam Muhammad Basiuni Imran (1885-1976) Di Sambas." Medina-Te : Jurnal Studi Islam, vol. 15, no. 1, August 2, 2019.75-91. https://doi. org/10.19109/medinate.v15i1.3542.

Tim Penyusun, Kamus Besar Bahasa Indonesia. Jakarta: Balai Pustaka, 1990.

Truna, Dody S. Pendidikan Agama Islam Berwawasan Multikulturalisme. Jakarta: Kementerian Agama RI, 2010.

Yunus, Mahmud, Sejarah Pendidikan Islam Di Indoenesia. Jakarta: Mahmud Yunus wadzuriyyah, 2008. 